\title{
PATTERN AND OUTCOME OF ASSAULTED PENETRATING THORACIC AND ABDOMINAL TRAUMA CASES: A TWO YEARS PROSPECTIVE STUDY
}

\author{
Mofrih M. Hegazy and Shireen R. Slima \\ Forensic Medicine and Clinical Toxicology department, Faculty of Medicine, Menoufia \\ University
}

\section{Corresponding author:}

Mofrih Mohammad Hegazy

Assistant professor in Forensic Medicine and Clinical Toxicology department, Faculty of

Medicine, Menoufia University, Egypt.

E. mail: mofrihhegazy@yahoo.com

Mobile phone: 01012897290

Background: There is a worldwide increase in the prevalence of assaulted penetrating thoracic and abdominal trauma which may lead to disabilities and death. Aim: To describe the pattern and predictors of outcome in assaulted penetrating thoracic and abdominal trauma. Methods: A two years prospective study was conducted on 123 patients with assaulted penetrating thoracic and abdominal trauma who were admitted to Menoufia University Hospital during the period from the $1^{\text {st }}$ January 2017 to the $31^{\text {th }}$ December 2018. For each case, demographic data, circumstances of trauma were taken. Also, general and local examination of injury was performed and findings in penetrating wounds were reported after investigation and surgical explorations. Outcome of cases either death or survived was determined. Results: Abdominal injuries constituted 58.5\% while thoracic injury was presented $(31.7 \%)$ of cases. The most frequent subjects aged from $20-<30$ years $(46.3 \%)$, males $(95.1 \%)$ and stab was the most common cause of injury (90.3\%).The intestinal injury was the most frequently injured organ (16.3\%) followed by spleen (12.2). The majority of patients survived $(90.2 \%$ ) and only $9.8 \%$ died. Mechanical ventilation, hypotension, delayed time for hospital arrival, gunshot injury, organ injury, hemoperitoneum and combined thoracic and abdominal injuries were the most predicting factor for mortality in the studied cases Conclusion: Penetrating thoracic and abdominal injuries caused by assault were common among middle aged single males and caused by stab. Delayed hospital arrival, hypotension and combined thoracic and abdominal injuries and gunshot trauma were predictors of death among the studied cases. The overall outcome was satisfactory. Recommendations: Rapid emergency transport of victims and rapid resuscitation should help to reduce the mortality from penetrating thoracic and abdominal injuries. Also, preventive strategies focused on reduction of violent crimes and social conflicts were necessary.

\section{Keywords:}

Assault; Penetrating; Thoracic injury; Abdominal injury; Pattern; Outcome.

\section{INTRODUCTION}

Injury to the Abdomen and thorax has always been considered as one of the most critical injuries inflicted upon the body. Penetrating thoracic or abdominal or combined injuries are one of the common injuries caused by assault (Dodia and Sansiya 2015). Penetrating stab injuries, especially deep injuries involving internal organs and large vessels in the chest or abdomen, can lead to infections, shock and death (Mnguni et al., 2012). Fatal outcome may occur through vital organ injury or bleeding from large blood vessels (Begum et al., 2014).

Penetrating wound is applied to wound which passes through the tissues, enters a body cavity, like abdominal cavity or thoracic cavity (Begum et al., 2014). Penetrating trauma from either gunshot 
wounds or stab injuries is a major healthcare problem (Johannesdottir et al., 2019). The severity of the injury varies widely depending on the site of body involved, the characteristics of the penetrating object, and the amount of energy transmitted to the tissues (Patel et al., 2016).

Stabbing is one of the most frequent ways of committing homicide, which may result from any sort of enmity, family dispute, quarrel with friends or even for snatching valuables. (Singh et al., 2004) It is produced when the force is delivered along the long axis of a narrow or pointed weapon, such as knife, dagger, nail, needle, spear, arrow, screw driver, in the depth of the body. Its depth is more than its length and width on skin that makes it so often fatal (Begum et al., 2014).

Assaulted penetrating trauma becomes a public health problem due to increasing levels of violence in the Egyptian society (El Shehaby et al., 2018). Moreover, penetrating thoracic and abdominal injuries are one of the common injuries caused by assault and are associated with high morbidity and fatality. Therefore, this study aimed to determine the pattern and outcome of assaulted penetrating thoracic and abdominal trauma admitted to Menoufia University Hospital.

\section{SUBJECT AND METHODS}

\section{I: Subject:}

This was a two years prospective study carried on one hundred twenty three who admitted to Menoufia University Hospital during the period from the $1^{\text {st }}$ January 2017 to the $31^{\text {th }}$ December 2018 .

For the purpose of the study, all cases of assaulted penetrating thoracic / abdominal or combined injuries were recruited. Penetrating injury is applied to wound which passes through the tissues, enters thoracic and/ or abdominal cavities.

Exclusion criteria included: all deaths on arrival; severely injured cases that did not respond to resuscitation attempts at emergency department; patients who were discharged against medical advice and lost to follow up; patient with suicidal or accidental thoracic and abdominal injuries.

\section{II: Methods:}

Data was collected from the victims, their relatives or health care workers. It included the following: demographic data (gender, age and residence), circumstances of trauma (time of hospital arrival, assailant, time from trauma to hospital presentation, cause of injury and type of weapon used). Revised Trauma Score (RTS) was calculated from blood pressure, Glasgow Coma Scale, and respiratory rate to provide a scored physiological assessment of the patient (Rapsang and Shyam, 2015).

Clinical examination was performed including both general examination (vital signs and sites of associated injuries if present) and local examination of injury regarding anatomical region (thorax, abdomen or combined), site and side, associated wounds. In addition, findings in penetrating wounds in the thorax (pneumothorax, hemothorax, lung tear, bronchial tear) and abdomen (pneumoperitoneum and organ injuries) were reported after investigation and surgical explorations of cases. Also, admission to ICU, blood transfusion and the need of mechanical ventilation were recorded. The outcome of cases was categorized as survived (with or without infirmity) and died.

This study was approved by the Menoufia Faculty of Medicine Ethical Committee. Also, a written informed consent was fulfilled by the studied cases or his guardian to participate in this study after explanation of the study aim by the authors. All collected personal information was treated confidentially.

\section{Statistical analysis:}

Data was statistically analyzed by IBM, SPSS Version 22 software (SPSS, Chicago, IL, USA). Median, interquartile range (IQR), number and percent were described. Qui square test $\left(\chi^{2}\right)$ was applied for comparison between two groups regarding the qualitative variables. $\mathrm{Z}$ test 
was used for comparison between two proportions within the same group. Binary logistic regression analysis was applied to verify predictors of death in the studied cases. A p-value <0.05 was considered statistically significant.

\section{RESULTS}

A total of 123 cases of thoracic and abdominal injuries were included in the present study. The most frequent subjects were among the age group from $20-<30$ years $(46.3 \%)$, males $(95.1 \%)$ with male to female ratio 19.5:1, from urban areas $(58.5 \%)$. No relation was present between victims and assailant in $43.9 \%$ of cases. About $43 \%$ of cases came to the hospital after 60-120 minutes following injury. The median value RTS was $6.8 \%$. More than half of cases $(58.5 \%)$ stayed at hospital for less than seven days. The majority of patients were cured (90.2\%) and only $9.8 \%$ died. Splenectomy was performed in $12.2 \%$ of cases while nephrectomy was applied in only $2.4 \%$ of them as shown in table 1.

Regarding clinical data, most patients were presented with decreased systolic $(71.5 \%)$ and diastolic blood pressure $(58.5 \%)$, normal respiratory rate $(52 \%)$. decreased hemoglobin level was detected in $74 \%$ of cases. About two third of them (65\%) were admitted to ICU and mechanical ventilation (respiratory rate $>35$ cycle/m, $\mathrm{PaO}_{2}<50 \mathrm{mmHg}, \mathrm{PaCO}_{2}>60$ $\mathrm{mmHg}$ and blood pressure $<80 / 50 \mathrm{mmHg}$ ) was applied to $29.3 \%$ of cases as shown in table 2.

Table 3 showed that, stab was the most common cause of injury $(90.3 \%)$ and gunshot firearm caused about $9.7 \%$ of injuries. Knife was used in about two third of cases $(65.9 \%)$. Abdominal injuries constituted more than half of the studied cases $(58.5 \%)$ while thoracic injury was presented in nearly one third $(31.7 \%)$ of them. Combined thoracic and abdominal injuries were in $9.8 \%$ of cases. Only penetrating injuries were found in $65 \%$ of cases while associated with cut wound in $17.1 \%$, with contusion in $12.2 \%$ and with rib fracture in $5.7 \%$. Associated other sites of injuries were head and neck (13\%), extremities (18.7\%) and genitalia (3.3\%).

The most frequent sites of injuries were left chest and umbilical areas $(24.4 \%$ of cases for each) followed by left upper abdomen (19.5\%) as illustrated fig (1). Hemoperitoneum was found in $43.9 \%$ while hemothorax, pneumothorax and pneumohemothorax were present in (26.0\%, $8.9 \%$ and $11.4 \%$; respectively). Organ injury was presented in $43.9 \%$ cases. Among these cases, intestine was the most common organ injured $(16.3 \%)$ followed by spleen (12.2\%), lung and stomach (4.1\% for each) as illustrated in fig (2).

Dead cases were significantly associated with abnormal systolic and diastolic blood pressure (100\% for each), with abnormal respiratory rate $(91.7 \%)$ who was admitted to ICU $(91.7 \%)$ and connected to mechanical ventilation $(66.7 \%)$. Also, there was a significant lower median values of RTS in dead cases than cured ones $(p<0.001)$ as shown in table 4.

Prolonged duration passed from the occurrence of injury to hospital arrival (41.7\% among > $120 \mathrm{~min}, 50.0 \%$ among 60-120 min) was significantly related to death in the studied cases. Also, gunshot, combined thoracic and abdominal injuries, hemoperitoneum and organ injury were associated with mortality $(66.7 \%, 50 \%$, $50 \%$ and $50 \%$; respectively) as shown in table 5 .

Binary logistic regression analysis for relevant predictors of death in thoracic and abdominal trauma cases in table 6 revealed that, the most predictors of death were cases who needed mechanical ventilation $(\mathrm{OR}=13.17)$ abnormal (Hypotension) systolic blood pressure (OR=12.51), > 120 min time passed after injury to hospital arrival and presentation $(\mathrm{OR}=10.56)$, gunshot injury $(\mathrm{OR}=5.81)$, organ injury $(\mathrm{OR}=2.74)$, hemoperitoneum $(\mathrm{OR}=3.41)$ and combined thoracic and abdominal injuries $(\mathrm{OR}=1.47)$ as shown in table 6 . 
Table (1): Characteristics of assaulted penetrating thoracic and abdominal trauma cases

\begin{tabular}{|c|c|c|}
\hline \multirow{2}{*}{ Variables } & \multicolumn{2}{|c|}{ Trauma cases $(n=123)$} \\
\hline & No & $\%$ \\
\hline \multicolumn{3}{|l|}{ Age (years): } \\
\hline $7-<20$ & 18 & 14.6 \\
\hline $20-<30$ & 57 & 46.3 \\
\hline $30-<40$ & 27 & 22.0 \\
\hline $40-<50$ & 15 & 12.2 \\
\hline$\geq 50$ & 6 & 4.9 \\
\hline \multicolumn{3}{|l|}{ Sex: } \\
\hline Male & 117 & 95.1 \\
\hline Female & 6 & 4.9 \\
\hline \multicolumn{3}{|l|}{ Marital Status: } \\
\hline Single & 85 & 69.1 \\
\hline married & 38 & 30.9 \\
\hline \multicolumn{3}{|l|}{ Residence: } \\
\hline Rural & 51 & 41.5 \\
\hline Urban & 72 & 58.5 \\
\hline \multicolumn{3}{|l|}{ Time of hospital arrival: } \\
\hline Morning & 12 & 9.8 \\
\hline Afternoon & 75 & 61.0 \\
\hline At night & 36 & 29.3 \\
\hline \multicolumn{3}{|l|}{ Assailant: } \\
\hline Relatives & 15 & 12.2 \\
\hline Neighbors & 33 & 26.8 \\
\hline Friends & 21 & 17.1 \\
\hline No relation & 54 & 43.9 \\
\hline \multicolumn{3}{|l|}{ Referral: } \\
\hline Yes & 37 & 30.1 \\
\hline No & 86 & 69.9 \\
\hline \multicolumn{3}{|l|}{ Duration from injury to hospital presentation (min): } \\
\hline$<30$ & 24 & 19.5 \\
\hline $30-59$ & 24 & 19.5 \\
\hline $60-120$ & 53 & 43.1 \\
\hline$>120$ & 22 & 17.9 \\
\hline \multicolumn{3}{|l|}{ Duration of hospital stay (days): } \\
\hline$<7$ & 72 & 58.5 \\
\hline $7-14$ & 30 & 24.4 \\
\hline$\geq 14$ & 21 & 17.1 \\
\hline \multicolumn{3}{|l|}{ Outcome: } \\
\hline Died & 12 & 9.8 \\
\hline Survived & 111 & 90.2 \\
\hline Survived with infirmity & 18 & 14.6 \\
\hline Splenectomy & 15 & 12.2 \\
\hline Nephrectomy & 3 & 2.4 \\
\hline
\end{tabular}


Table (2): Clinical data for assaulted penetrating thoracic and abdominal trauma cases at hospital admission

\begin{tabular}{|l|l|l|}
\hline \multirow{2}{*}{ Variables } & \multicolumn{2}{|l|}{$\begin{array}{l}\text { Thoracic and abdominal } \\
\text { trauma cases (n=123) }\end{array}$} \\
\cline { 2 - 3 } & No & \% \\
\hline SBP & & \\
Normal & 35 & 28.5 \\
Hypotension & 88 & 71.5 \\
\hline DBP & \multicolumn{2}{|l|}{} \\
Normal & 51 & 41.5 \\
Hypotension & 72 & 58.5 \\
\hline RR & & \\
Normal & 64 & 52.0 \\
Abnormal & 59 & 48.0 \\
\hline RTS & 6.80 & \\
Median (IQR) & $(5.90-7.2)$ \\
\hline Hb\% & \multicolumn{2}{|l}{} \\
Normal & 21 & 17.1 \\
Decreased & 102 & 82.9 \\
\hline Blood transfusion: & & \\
Yes & 91 & 74.0 \\
No & 32 & 26.0 \\
\hline ICU admission: & \multicolumn{2}{|l}{} \\
Yes & 80 & 65.0 \\
No & 43 & 35.0 \\
\hline Mechanical ventilation: & & 29.3 \\
Yes & 36 & 70.7 \\
No & 87 & \multicolumn{2}{|l}{} \\
\hline
\end{tabular}

SBP: Systolic blood pressure; DBP: Diastolic blood pressure; RTS: Revised trauma score 
Table (3): Injury data for assaulted penetrating thoracic and abdominal trauma cases

\begin{tabular}{|c|c|c|}
\hline \multirow{2}{*}{ Variables } & \multicolumn{2}{|c|}{$\begin{array}{c}\text { Thoracic and abdominal } \\
\text { trauma cases }(\mathbf{n = 1 2 3})\end{array}$} \\
\cline { 2 - 3 } & No & \% \\
\hline Cause of injury: & 111 & 90.3 \\
Stab penetrating & 12 & 9.7 \\
Gunshot firearm & & \\
Type of weapon: & 81 & 65.9 \\
Knife & 6 & 4.9 \\
Scissor & 6 & 4.9 \\
Dagger & 9 & 7.3 \\
Sickle & 9 & 7.3 \\
Sword & 12 & 9.7 \\
firearm & & \\
Thorax & 39 & 31.7 \\
Abdomen & 72 & 58.5 \\
Anatomical region of injury: & 12 & 9.8 \\
\hline Combined thorax and abdomen & & \\
Associated wound: & 80 & 65.0 \\
Penetrating only & 7 & 5.7 \\
Penetrating with rib fracture & 21 & 17.1 \\
Penetrating with cut wound & 15 & 12.2 \\
Penetrating with contusion & $\mathbf{4 3}$ & $\mathbf{3 5 . 0}$ \\
\hline Associated sites of other injury: & 16 & 13.0 \\
Head/neck & 23 & 18.7 \\
Extremities & 4 & 3.3 \\
Genitalia & & \\
\hline
\end{tabular}

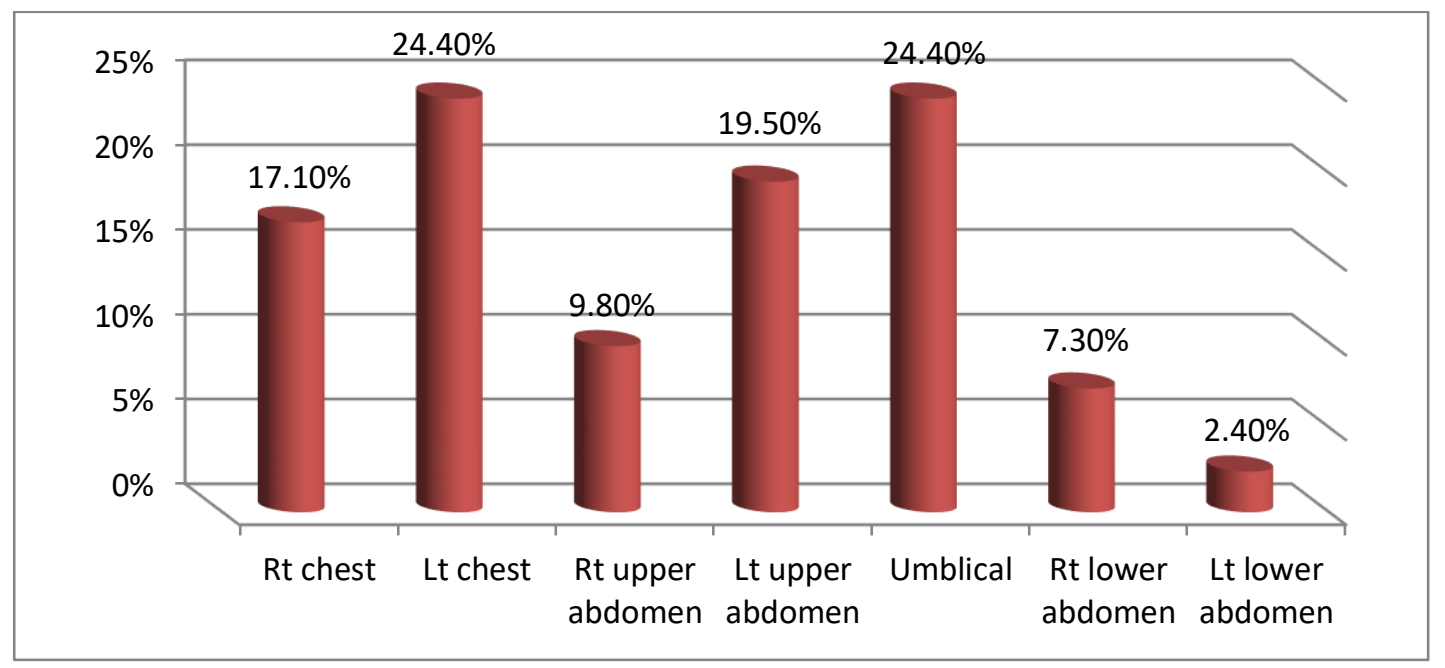

Figure (1): Percent distribution of injury sites in the studied cases. 


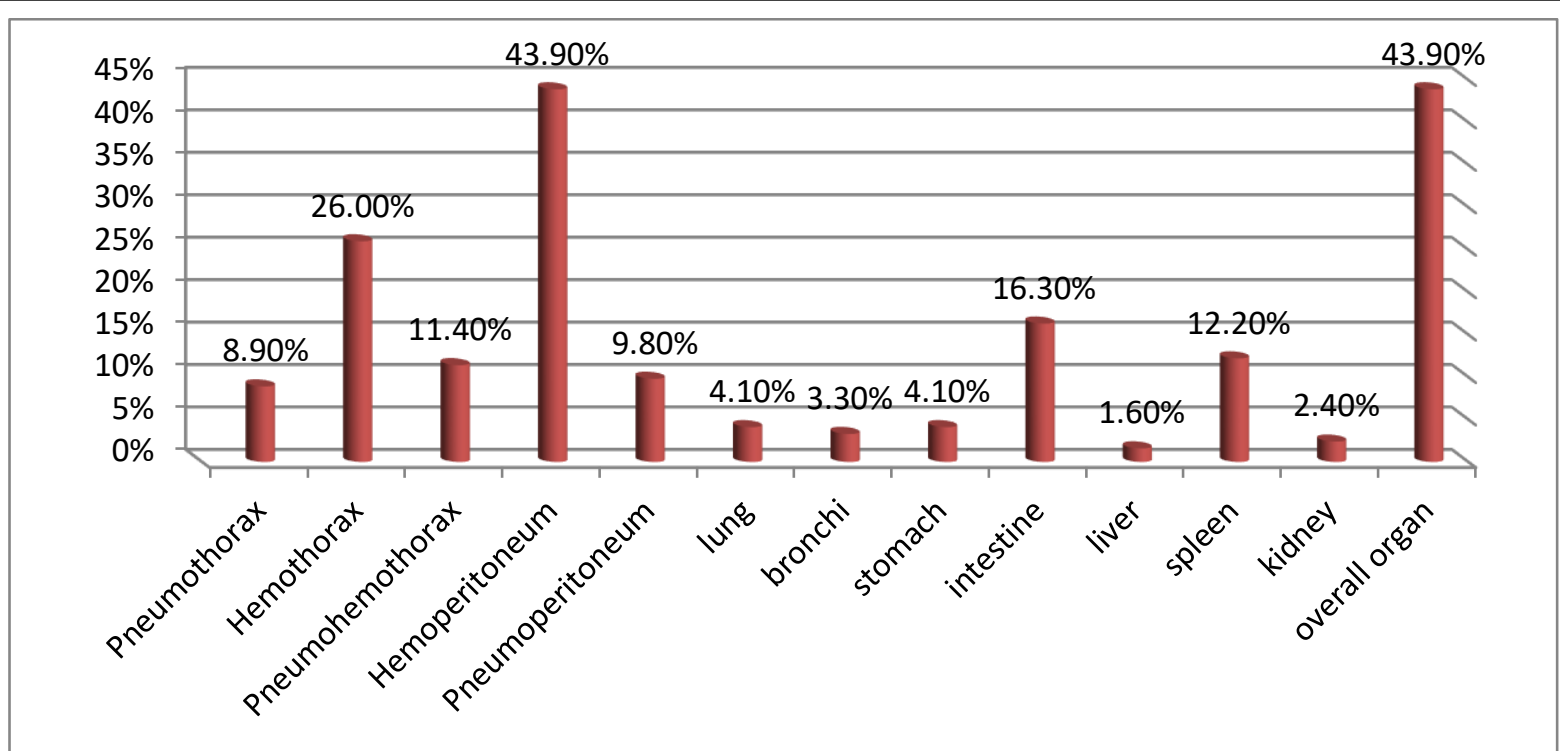

Figure (2): Percent distribution of findings in penetrating in the studied cases.

Table (4): Outcome of assaulted penetrating thoracic and abdominal trauma cases regarding clinical data at hospital admission

\begin{tabular}{|c|c|c|c|c|}
\hline \multirow[b]{2}{*}{ Variables } & \multicolumn{2}{|c|}{$\begin{array}{l}\text { Outcome of thoracic and } \\
\text { abdominal trauma cases }\end{array}$} & \multirow[b]{2}{*}{$\begin{array}{c}\text { Test of } \\
\text { significance }\end{array}$} & \multirow[b]{2}{*}{ p-value } \\
\hline & $\begin{array}{c}\begin{array}{c}\text { Survived } \\
(\mathbf{n}=111) \\
\text { No }(\%)\end{array}\end{array}$ & $\begin{array}{c}\text { Died } \\
(\mathrm{n}=12) \\
\text { No }(\%)\end{array}$ & & \\
\hline $\begin{array}{c}\text { SBP }(\mathbf{m m H g}): \\
\text { Normal } \\
\text { Hypotension }(<90) \\
\end{array}$ & $\begin{array}{ll}35 & (31.5) \\
76 & (68.5) \\
\end{array}$ & $\begin{array}{cc}0 & (0) \\
12 & (100.0) \\
\end{array}$ & $\chi^{2}=5.29$ & 0.021 \\
\hline $\begin{array}{c}\text { DBP }(\mathbf{m m H g}): \\
\text { Normal } \\
\text { Hypotension }(<60) \\
\end{array}$ & $\begin{array}{ll}51 & (45.9) \\
60 & (54.1) \\
\end{array}$ & $\begin{array}{cc}0 & (0) \\
12 & (100.0) \\
\end{array}$ & $\chi^{2}=579.19$ & $<0.001$ \\
\hline $\begin{array}{l}\text { RR }(\text { cycle/min) } \\
\text { Normal }(12-25) \\
\text { Abnormal } \\
\end{array}$ & $\begin{array}{ll}63 & (56.8) \\
48 & (43.2) \\
\end{array}$ & $\begin{array}{cc}1 & (8.3) \\
11 & (91.7) \\
\end{array}$ & $\chi^{2}=10.17$ & 0.001 \\
\hline $\begin{array}{c}\text { RTS } \\
\text { Median (IQR) } \\
\end{array}$ & $\begin{array}{c}7.10 \\
(6.70-7.20) \\
\end{array}$ & $\begin{array}{c}4.20 \\
(3.95-4.68) \\
\end{array}$ & $\mathrm{U}=5.48$ & $<0.001$ \\
\hline $\begin{array}{c}\text { Hb\% } \\
\text { Normal } \\
\text { Abnormal } \\
\end{array}$ & $\begin{array}{l}19(17.1) \\
92(82.9)\end{array}$ & $\begin{array}{c}2(6.7) \\
10(83.3)\end{array}$ & $\chi^{2}=0.01$ & 0.969 \\
\hline $\begin{array}{c}\text { Blood transfusion: } \\
\text { Yes } \\
\text { No }\end{array}$ & $\begin{array}{l}82(73.9) \\
29(26.1)\end{array}$ & $\begin{array}{l}9(75.0) \\
3(25.0)\end{array}$ & $\chi^{2}=0.01$ & 0.933 \\
\hline $\begin{array}{c}\text { ICU admission: } \\
\text { Yes } \\
\text { No }\end{array}$ & $\begin{array}{ll}69 & (62.2) \\
42 & (37.8) \\
\end{array}$ & $\begin{array}{l}11(91.7) \\
1 \quad(8.3)\end{array}$ & $\chi^{2}=4.15$ & 0.042 \\
\hline $\begin{array}{c}\text { Mechanical ventilation: } \\
\text { Yes } \\
\text { No } \\
\end{array}$ & $\begin{array}{l}28(25.2) \\
83(74.8)\end{array}$ & $\begin{array}{ll}8 & (66.7) \\
4 & (33.3) \\
\end{array}$ & $\chi^{2}=8.98$ & 0.003 \\
\hline
\end{tabular}


Table (5): outcome of assaulted penetrating thoracic and abdominal trauma cases regarding injury data at hospital admission

\begin{tabular}{|c|c|c|c|c|}
\hline \multirow[b]{2}{*}{ Variables } & \multicolumn{2}{|c|}{$\begin{array}{l}\text { Outcome of thoracic and } \\
\text { abdominal trauma cases }\end{array}$} & \multirow[b]{2}{*}{$\chi^{2}$} & \multirow[b]{2}{*}{ p-value } \\
\hline & $\begin{array}{c}\begin{array}{c}\text { Survived } \\
(\mathbf{n}=111)\end{array} \\
\text { No }(\%)\end{array}$ & $\begin{array}{c}\text { Died } \\
(\mathrm{n}=12) \\
\text { No }(\%)\end{array}$ & & \\
\hline 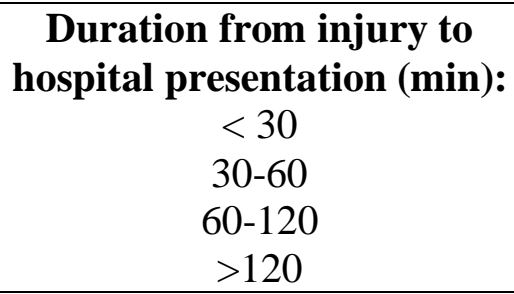 & $\begin{array}{l}24(21.6) \\
23(20.7) \\
47(42.4) \\
17(15.3)\end{array}$ & $\begin{array}{c}0 \\
1(8.3) \\
6(50.0) \\
5(41.7) \\
\end{array}$ & 7.80 & 0.050 \\
\hline $\begin{array}{l}\text { Cause of injury: } \\
\text { Stab penetrating } \\
\text { Gunshot firearm }\end{array}$ & $\begin{array}{c}107(96.4) \\
4(3.6)\end{array}$ & $\begin{array}{l}4(33.3) \\
8(66.7)\end{array}$ & 48.92 & $<0.001$ \\
\hline $\begin{array}{c}\text { Anatomical region injuries: } \\
\text { Thorax } \\
\text { Abdomen } \\
\text { Combined }\end{array}$ & $\begin{array}{c}39(35.1) \\
66(59.5) \\
6(5.4)\end{array}$ & $\begin{array}{c}0 \\
6(50.0) \\
6(50.0)\end{array}$ & 26.46 & $<0.001$ \\
\hline $\begin{array}{l}\text { Associated wound: } \\
\text { Penetrating only } \\
\text { Penetrating with rib fracture } \\
\text { Penetrating with cut wound } \\
\text { Penetrating with contusion }\end{array}$ & $\begin{aligned} & 68(61.3) \\
& 7(6.3) \\
& 21(18.9) \\
& 15(13.5) \\
&\end{aligned}$ & $\begin{array}{c}12(100.0) \\
0 \\
0 \\
0 \\
\end{array}$ & 7.15 & 0.067 \\
\hline $\begin{array}{c}\text { Sites of other injury: } \\
\text { Head } \\
\text { Extremities } \\
\text { Genitalia }\end{array}$ & $\begin{array}{c}31(27.9) \\
10(9.0) \\
17(15.3) \\
4(3.6)\end{array}$ & $\begin{array}{c}12(\mathbf{1 0 0 . 0}) \\
6(50.0) \\
6(50.0) \\
0\end{array}$ & $\begin{array}{c}2.0 \\
10.52 \\
8.00 \\
\end{array}$ & $\begin{array}{l}0.157 \\
\mathbf{0 . 0 0 1} \\
\mathbf{0 . 0 0 5}\end{array}$ \\
\hline $\begin{array}{c}\text { Findings: } \\
\text { Pneumothorax } \\
\text { Hemothorax } \\
\text { Pneumohemothorax } \\
\text { Hemoperitoneum } \\
\text { Pneumoperitoneum } \\
\text { Organ injury }\end{array}$ & $\begin{array}{c}11(8.9) \\
29(26.1) \\
12(10.8) \\
43(38.7) \\
11(9.9) \\
45(40.5)\end{array}$ & $\begin{array}{c}0 \\
3(25.0) \\
2(16.7) \\
11(91.7) \\
1(8.3) \\
9(75.0)\end{array}$ & $\begin{array}{l}Z=0.61 \\
Z=0.26 \\
Z=0.13 \\
Z=3.02 \\
Z=0.34 \\
Z=1.98\end{array}$ & $\begin{array}{l}0.541 \\
0.793 \\
0.898 \\
\mathbf{0 . 0 0 1} \\
0.736 \\
\mathbf{0 . 0 5 0}\end{array}$ \\
\hline
\end{tabular}


Table (6): Binary logistic regression analysis for relevant predictors of death in thoracic and abdominal trauma cases

\begin{tabular}{|c|c|c|c|c|}
\hline \multirow{2}{*}{ Predictors } & \multirow{2}{*}{ p-value } & \multirow{2}{*}{ OR } & \multicolumn{2}{|c|}{ 95\% C.I. } \\
\hline & & & Lower & Upper \\
\hline $\begin{array}{l}\text { SBP }(\mathbf{m m H g}): \\
\text { Normal: } \\
\text { Hypotension } \\
\end{array}$ & $<0.001$ & $\begin{array}{c}\text { Reference } \\
12.51\end{array}$ & 7.28 & 21.39 \\
\hline $\begin{array}{c}\text { Mechanical ventilation: } \\
\text { Yes } \\
\text { No } \\
\end{array}$ & $<0.001$ & $\begin{array}{c}13.17 \\
\text { Reference }\end{array}$ & 5.86 & 29.74 \\
\hline 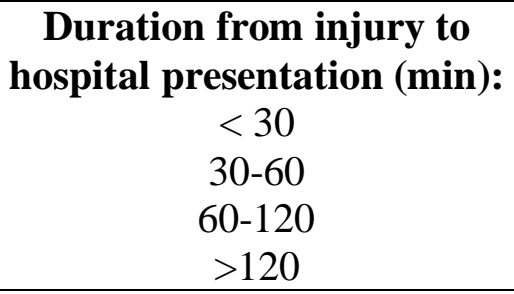 & $\begin{array}{c}0.123 \\
\mathbf{0 . 0 2 5} \\
<\mathbf{0 . 0 0 1} \\
\end{array}$ & $\begin{array}{c}\text { Reference } \\
0.27 \\
1.31 \\
10.56 \\
\end{array}$ & $\begin{array}{c}0.10 \\
0.031 \\
6.52 \\
\end{array}$ & $\begin{array}{c}0.74 \\
0.84 \\
17.10 \\
\end{array}$ \\
\hline $\begin{array}{l}\text { Cause of injury: } \\
\text { Stab penetrating } \\
\text { Gunshot firearm } \\
\end{array}$ & $<0.001$ & $\begin{array}{c}\text { Reference } \\
5.81\end{array}$ & 3.08 & 10.96 \\
\hline $\begin{array}{c}\text { Anatomical region injuries: } \\
\text { Thorax } \\
\text { Abdomen } \\
\text { Combined } \\
\end{array}$ & $\begin{array}{l}0.025 \\
0.008 \\
\end{array}$ & $\begin{array}{c}\text { Reference } \\
0.31 \\
1.47\end{array}$ & $\begin{array}{l}0.30 \\
1.46\end{array}$ & $\begin{array}{l}0.86 \\
1.95 \\
\end{array}$ \\
\hline Hemoperitoneum & $<0.001$ & 3.41 & 1.62 & 5.28 \\
\hline Organ injury & $<0.050$ & 2.74 & 2.41 & 4.83 \\
\hline
\end{tabular}

B: beta coefficient OR: Odds ratio CI: confidence interval

DBP, RR, RTS, ICU admission were included in regression model but were non-significant predictors.

\section{DISCUSSION}

Penetrating trauma considered one of the common injuries caused by assault (Vyhnánek et al., 2011). In the present study, abdominal injuries were more prevalent than thoracic injuries $(58.5 \%$ vs $31.7 \%$ ) and $9.8 \%$ combined thoracoabdominal injuries as the abdomen is the third most commonly injured region (Hemmila et al., 2008). This result was coincided with Vyhnánek et al. (2011) who found that among patients admitted to Trauma center in Prague, 53\% suffered from penetrating abdominal injuries, $36 \%$ from thoracic injuries and $11 \%$ from combined, thoraco-abdominal injuries.

Injuries were more common among males with a male to female ratio 19.5:1 this might be due to their propensity to violence and due to their greater exposure to outdoor activities (Abdel-Hameed et al., 2017). This result was lower than the result of an Indian study (Dodia et al., 2015) where male to female ratio was $24: 1$ but it was carried out on a smaller sample and for a shorter duration than the present study and included perforating injuries caused by accidental and suicidal manners. In another study, the male to female ratio was 12.3: 1 among abdominal trauma patients (Musau et al., 2006).

The most common age group in assaulted penetrating thoracic and abdominal trauma was the age group from $20-<30$ years followed by the age from $30-$ $<40$ years as they are the productive age involved in work activities, more active, and more liable to participate in violence and homicidal attempts. Similar results were obtained in previous studies from Egypt (Saleem et al., 2016), India (Panchal et al., 2016), Greece (Ioannidis 
et al., 2012) and Ghana (Ohene-Yeboah et al., 2010).

Regarding the time consumed from the occurrence of trauma to hospital arrival, about $61 \%$ of cases reach hospital after $60 \mathrm{~min}$ as Menoufia University hospitals receive cases from the entire governorate and cases were referred from central hospitals all district, also due to delay transport of injured persons. The time gap from trauma and arrival in a hospital is a very critical in dealing with trauma and determine its outcome (Tariq et al., 2011).

Stab penetrating constituted the major cause of injury among the studied cases of thoracic and abdominal injuries (90.3\%) followed by gunshot firearm $(9.7 \%)$. Stabbing by knife is much more common in this study causing injuries in $65.9 \%$ of cases, this also previously reported by Lockyer et al., (2013) as it is easily available and no license is needed to carry like the firearms (Agarwal and Bindal, 2017). Also, stabbing was found to be the most common cause of penetrating abdominal trauma than gunshot wounds $(66.67 \%$ versus $33.33 \%)$ in a previous Egyptian study (Saleem et al., 2016) but the percentage of firearm was higher as this study was conducted in upper Egypt where firearm weapons were more available. Moreover, chest and abdomen were reported as the most common sites of stab wounds (Johannesdottir et al., 2019; Nishimura et al., 2017). However, gunshot was the most common cause of penetrating injuries in other studies (Lone et al., 2001).

The left side of the chest and the umbilical region in the abdomen were more frequently affected regions by trauma (24.4\%) in the current study. The left part of the chest was more common site of trauma where popular knowledge about the heart site. The overall left-sided injuries outnumbered right-sided injuries because assailants were mostly right handed (Yazici et al., 2012). Similarly, Dodia et al. (2015) found that $36 \%$ of penetrating thoracic and abdominal trauma cases had entry wound in umbilical region, followed by right iliac, right lumbar and lateral chest with $16 \%$ in each.

Organ injury was present in $43.9 \%$ cases. Among these cases, Intestinal injury was the most frequently affected organ $(16.3 \%)$ as intestine occupies a large portion of the abdominal cavity (Tillu et al., 2017). In another study in Sudan (Omar et al., 2014), the most frequent affected organs were intestine (72.5\%) followed by stomach and spleen each in $14.5 \%$ of cases. The organs affected depend on the site of trauma.

Spleen constituted the second common injured organ $(12.2 \%)$ as the trauma in the left upper abdomen is about $19.5 \%$ among the studied cases. The prevalence of splenic injuries in this study was similar to previous studies (Asuquo et al., 2012; Ohene-Yeboah et al., 2010; MonzonTorres and Ortega-Gonzalez, 2004). However, Hemmati et al. (2013) reported higher percentage of splenic injuries in patients with penetrating abdominal injuries (24.2\%).

In patients with chest trauma, hemothorax was the condition most often manifested $(26.0 \%)$ while pneumothorax presented in $8.9 \%$ of cases. Also, Ali Khan et al. (2009) declared that hemothorax and pneumothorax were the most prevalent lesions in 114 patients with chest trauma.

The overall outcome of penetrating thoracic and abdominal injuries in the current cases was satisfactory as than $90.2 \%$ survived. This result was consistent with other investigators (Lone et al., 2001) but was lower than that found by Hemmati et al. (2013) study in Iran $(95.7 \%)$ but their study included cases with chest and abdominal injuries caused by both blunt and penetrating trauma. The survival rate depends on many factors including availability and efficiency of health services. Hypotension and the need of mechanical ventilation at admission were the most significant predictors for 
death in the studied cases of thoracic and abdominal injuries. Hypovolemic shock arises in penetrating trauma due to hemorrhage. The presence of shock increase mortality rates in abdominal trauma cases as declared by other studies (Iflazoglu et al., 2015; Lund et al., 2011).

Time delayed more than $60 \mathrm{~min}$ from the occurrence of trauma to hospital arrival was another predictor for death in the present study. This finding was consistent with the study of Gad et al. (2012) who reported that $81.8 \%$ of fatal cases of penetrating abdominal trauma waited 60 to 90 minutes for emergency care.

Gunshot injury is still a significant predictor of death in the present study as two thirds of cases caused by gunshot died (8 cases from 12). Moreover, gunshot had more than five times higher mortality rate than stab wound $(\mathrm{OR}=5.81)$. This result coincided with many previous studies (Gad et al., 2012; Baradaran et al., 2007). The fatality of gunshot could be explained by the high kinetic energy induced by the high speed or velocity weapons that leads to more damaging powers to the tissues (Lichte et al., 2010).

Abdominal trauma only and combined thoracic and abdominal trauma were still significant predictors for death after regression analysis in relation to thoracic trauma only. Also, Iflazoglu et al. (2015) found that accompanying thoracic trauma was a significant risk factor for the development of complications and mortality in penetrating abdominal firearm injuries. In addition, organ injury was a predictor for death in this study and other studies.

Although Revised Trauma Score (RTS) was significantly lowered in dead cases than survived subjects but it didn't still a significant predictor for death in cases of thoracic and abdominal injuries after binary logistic regression analysis. RTS was calculated from blood pressure, Glasgow Coma Scale, and respiratory rate. Patients with thoracic or abdominal trauma may not be initially presented with changes in level of consciousness so, this may result in an overestimated RTS value leading to failure of mortality prediction in those patients depending on RTS (Alvarez et al., 2016).

This study was limited to small sample size for cases of penetrating thoracic and abdominal injuries as the study was conducted in a single hospital at Menoufia governorate. In spite these limitations, the study gives baseline information about the pattern and outcome of assaulted penetrating thoracic and abdominal trauma for future large scale studies in Egypt.

\section{CONCLUSIONS}

Penetrating thoracic and abdominal injuries caused by assault were common among middle aged single males and caused by stab. Delayed hospital arrival, hypotension and combined thoracic and abdominal injuries and gunshot trauma were predictors of death among the studied cases. The overall outcome was satisfactory.

\section{RECOMMENDATIONS}

Rapid emergency transport of victims and rapid resuscitation should help to reduce the mortality from penetrating thoracic and abdominal injuries. Also, preventive strategies focused on reduction of violent crimes and social conflicts were necessary.

\section{REFERENCES}

Abdel-Hameed, S.Y.; Ibrahim A.K.; Thabet, H.Z. and Mohamed, A.A (2017): Patterns of traumatic injuries and mortality in tertiary trauma center, Assiut university hospitals (from 2005 to 2012), Egypt J. Forensic Sci. Appli. Toxicol, 17 (1): 89108.

Agarwal, P. and Bindal, S.K. (2017): Prospective Study of Stab Injury of Abdomen. International Journal of Scientific Study, 5 (3): 67-72.

Aldemir, M.; Tachylidiz, I. and Girgin S. (2004): Predicting factors for mortality in penetrating abdominal trauma. Acta Chir Belg; 104:429-434. 
Alvarez, B.D.; Razente, D.; Lacerda, D.A.; Lother, N.S.; Von-Batahten, L.C. and Stahlschmidt, C. (2016): Analysis of the Revised Trauma Score (RTS) in 200 victims of different trauma mechanisms. Rev Col Bras Cir, 43(5):334-340.

Asuquo, M.; Umoh, M.; Nwagbara, V.; Ugare, G.; Agbor, C. and Japhet, E. (2012): Penetrating Abdominal Trauma: Expe-rience in a Teaching Hospital, Calabar, Southern Nigeria," International Journal of Clinical Medicine, 3(5): 426430.

Baradaran, H.; Salimi, J.; NassajiZavareh, M.; Khaji, A. and Rabbani, A. (2007): Epidemiological study of patients with penetrating abdominal trauma in Tehran-Iran. Acta Med Iran, 45: 305-308.

Begum, A.; Rabiul, H.; Begum, M.; Alam, A.; Akhter, G. and Tasmin T(2014): A Case Report on Stab Injury, Delta Med Col J, 2 (1):36-38.

Bordoni, P.H.C.; dos Santos, D.M.M.; Teixeira, J.S. and Bordoni, L.S. (2017): Deaths from abdominal trauma: analysis of 1888 forensic autopsies, Rev Col Bras Cir, 44 (6): 582-595.

Dodia, H. and Sansiya, K. (2015): A Study of Penetrating Thoracic and Abdominal Injuries, Journal of Dental and Medical Sciences, 14 (8): 64-95.

El Shehaby D.M.; Saleh M.A, Shahine M.S.; Mostafa M.S and Sayed M.M (December 2018): Did january 25th egyptian revolution change the medicolegal pattern and the trend of hospitalized injuries in upper egypt? A retrospective study. Egypt J. Forensic Sci. Appli. Toxicol, 18 (4):15-7.

Gad, M.A.; Saber, A.; Farrag, S.; Shams, M.E. and Elabban, G.M. (2012): Incidence, pattern and factors predicting mortality of abdominal injuries I Trauma patients. North Am Med Sci, 4: 129-34.

Hemmati, H. ; Kazemnezhad-Leili, E. ; Mohtasham-Amiri, Z. ; Darzi, A. ; Davoudi kiakalayeh, A. ; Dehnadi Moghadam, A.; et al. (2013): Evaluation of Chest and Abdominal Injuries in Trauma Patients Hospitalized in the
Surgery Ward of Poursina Teaching Hospital, Guilan, Iran. Archives of trauma research. 1. 161-5.

Hemmila, M.R. and Wahl, W.L. (2008): Management of the injured patients In: Dorethy GM, editor. Current Surgical Diagnosis and Treatment. New York: McGraw-Hill Medical: 227-228.

Iflazoglu, N.; Ureyen, O.; Oner, O.; Tusat, M. and Akcal, M. (2015): Complications and risk factors for mortality in penetrating abdominal firearm injuries: analysis of 120 cases. Int J Clin Exp Med, 8(4):6154-6162.

Ioannidis, O.; Varnalidis, I. and Papapostolou, D. (2012): Thoracoabdominal injuries: the general surgeon's perspective. Revista Medico-chirurgicala a Societatii de Medici si Naturalisti din Iasi. Jan-Mar, 116(1):175-181.

Johannesdottir, U.; Jonsdottir， G.M.; Johannesdottir, B.K.; Heimisdottir, A.A.; Eythorsson, E.; Gudbjartsson, T.; et al. (2019): Penetrating stab injuries in Iceland: a whole-nation study on incidence and outcome in patients hospitalized for penetrating stab injuries. Scand J Trauma Resusc Emerg Med, 27(1):7.

Khan, I.A.; Ghaffar, S.; Asif, S.; Zia ur, R.; Asad, S.; Ahmed, E.; et al. (2009): Management of thoracic trauma: experience at Ayub Teaching Hospital, Abbottabad. J Ayub Med Coll Abbottabad, 21(1):152-4.

Lichte, P.; Oberbeck, R.; Binnebosel, M.; Wildenauer, R.; Pape, H.C., Kobbe, P. (2010): A civilian perspective on ballistic trauma and gunshot injuries. Scand J Trauma Resusc Emerg Med, 18: 35.

Lockyer, A.; Oram, R.; Lopez, G.; Lutchminarain, N. and Meek S (2013): Patterns of injury in penetrating sharp trauma in a Provincial KwaZulu-Natal Hospital, African Journal of Emergency Medicine, 3: 67-70.

Lone, G.N.; Peer, G.Q.; Warn, A.k.; Bhat, A.M. and Warn, N.A. (2001): An experience with abdominal trauma in adults in Kashmir. JK Pract, 8: 225-30. 
Lund, H.; Kofoed, S.C.; Hillingso, J.G.; Falck-Larsen, C. and Svendsen, L.B. (2011): High mortality after emergency room laparotomy in haemodynamically unstable trauma patients. Dan Med Bull, 58: A4275.

Mnguni, M.N.; Muckart, D.J. and Madiba TE. (2012): Abdominal trauma in durban, South Africa: factors influencing outcome. Int Surg, 97:161-8.

Monzon-Torres, B. I. and OrtegaGonzalez, M. (2004): Penetrating Abdominal Trauma, SAJS, 42(1):11-13.

Musau, P.; Jani, P.G. and Owillah, F.A. (2006): Pattern and outcome of abdominal injuries at Kenyatta National Hospital, Nairobi. East Afr Med J, 83 (1):37-43.

Nishimura, T.; Sakata, H.; Yamada, T.; Terashima, M.; Shirai, K.; Yamada, I.; et al. (2017): Different patterns in abdominal stab wound in the self-inflicted and assaulted patients: an observational analysis of single center experience. Kobe J Med Sci, 63(1):E17-E21.

Ohene-Yeboah, M.; Dakubo, J.C.; Boakye, F. and Naeeder SB. (2010): Penetrating abdominal injuries in adults seen at two teaching hospitals in Ghana. Ghana Med J, 44(3):103- 8.

Omer, M.Y.; Hamza, A.A. and Musa, M.T. (2014): Penetrating Abdominal Injuries: Pattern and Outcome of Management in Khartoum. International Journal of Clinical Medicine, 5 (1): 18-22.

Panchal, H.A. and Ramanuj, A. M. (2016): The study of abdominal trauma: patterns of injury, clinical presentation, organ involvement and associated injury. International Surgery Journal, 3 (3):1392-1398.

Patel, P.; Gadhavi, J. and Parmar H. (2016): A study of blunt and penetrating abdominal trauma, its various patterns of injuries, and its management. Int J Med Sci Public Health, 5:1309-1312.
Rapsang, A.G. and Shyam, D.C. (2015): Scoring Systems of Severity in Patients with Multiple Trauma, Cir Esp, 93:213221.

Saleem, AE. A.; Abdul Raheem, O. A.; Abdallah, H. A. and Yousef, A. M. (2016): Epidemiological evaluation and outcome of pure abdominal trauma victims who underwent surgical exploratory laparotomy Al Azhar Assiut Medical Journal, 14:24-8

Sarma, B.; Ghormade, P.S. and Yadav, L. (2018): Homicidal stab injury over an extremely rare site: a case report, Int. J. of Allied Med. Sci. and Clin. Research, 6(3):761-766.

Singh, V.P.; Sharma, B.R.; Harish, D. and Vij, K. (2004): A Critical Analysis of Stab Wound on the Chest - A Case Report. JIAFM, 26(2):77-9.

Tariq, U. M.; Faruque, A.; Ansari, H.; Ahmad, M.; Rashid, U.; Perveen, S.; et al. (2011): Changes in the patterns, presentation and management of penetrating chest trauma patients at a level II trauma center in Southern Pakistan over the last two decades. Interactive CardioVascular and Thoracic Surgery, 12: 24-27.

Tillu, N.; Rathod, C.; Kumar, M. and Kumar V. (2017): A study to assess the 30 days outcome of penetrating injuries to the abdomen. Int Surg J, 4 (1): 64-74.

Vyhnánek, F.; Novák, L.; Jirava, D. and Ocadlík, M. (2011): Penetrating thoracic and abdominal injuries: diagnostic and therapeutic approach. Rozhledy $\mathrm{v}$ Chirurgii, 90 (11): 642-646.

Yazici, Ü.; Yazicioğlu, A.; Aydin, E.; Aydoğdu, K.; Kaya, S. and Karaoğlanoğlu, N. (2012): Penetrating chest injuries: analysis of 99 cases, Turk J Med Sci; 42 (6): 1082-1085. 


\section{نمط وعواقب حالات الإصابات النافذة للصدر والبطن الناجمة عن الاعتداعات: دراسة}

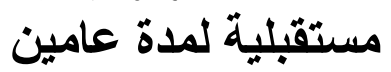

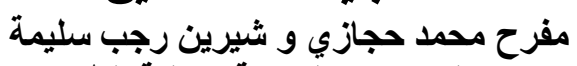

قسم الطب الثرعي والسموم الاكلينيكية - كلية الطب - جامعة المنوفينة

المقدمة: هنالك زيادة عالمية في إنتشار الإصابات النافذة للصدر و البطن والتي قد تؤدي إلى الإعاقة والموت.

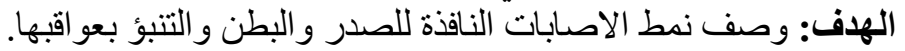

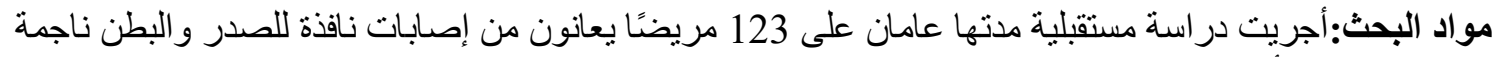

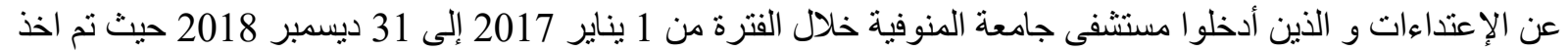

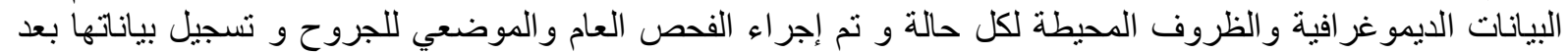

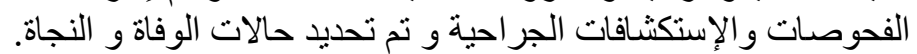

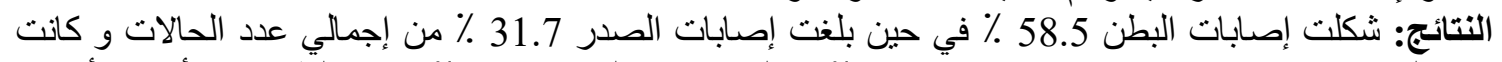

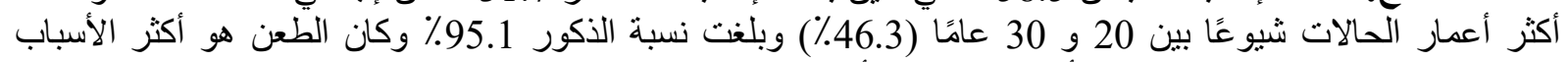

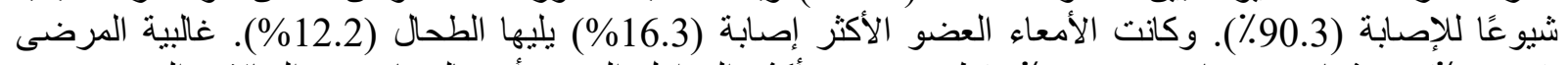

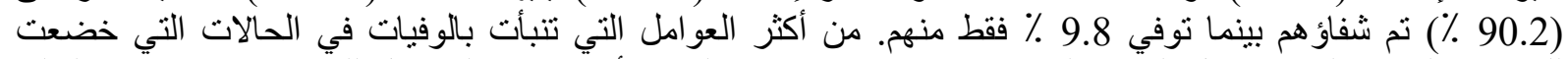

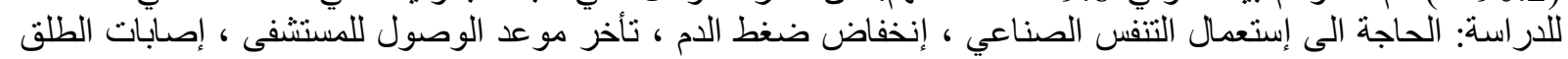

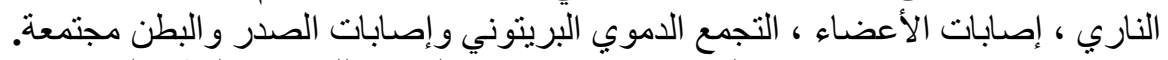

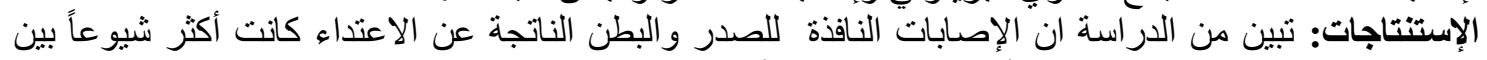

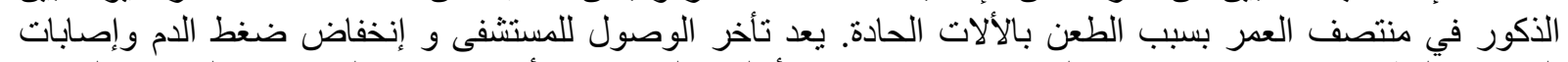

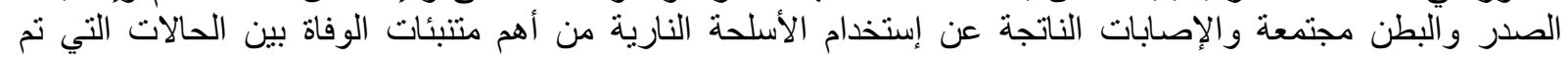

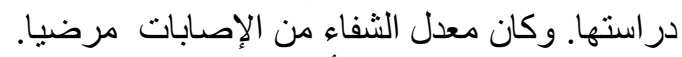

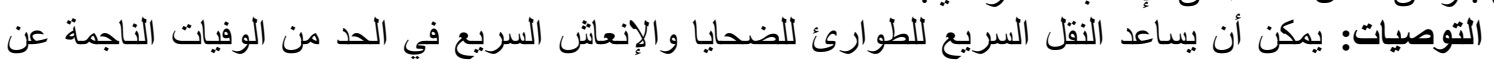

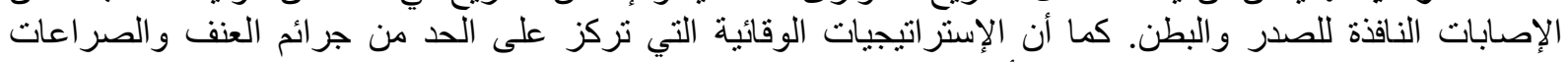

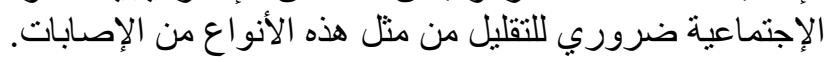

